\title{
"The status of small business growth and entrepreneurial start-up capital availability during the current extended economic downturn"
}

\section{AUTHORS}

ARTICLE INFO

DOI

RELEASED ON

JOURNAL

FOUNDER

\section{Lloyd J.F. Southern}

Lloyd J.F. Southern (2016). The status of small business growth and entrepreneurial start-up capital availability during the current extended economic downturn. Problems and Perspectives in Management, 14(1), 8-15. doi:10.21511/ppm.14(1).2016.01

http://dx.doi.org/10.21511/ppm.14(1).2016.01

Wednesday, 02 March 2016

"Problems and Perspectives in Management"

LLC "Consulting Publishing Company "Business Perspectives"
NUMBER OF REFERENCES

0

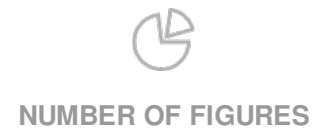

0

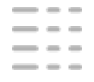

NUMBER OF TABLES

0

(c) The author(s) 2023. This publication is an open access article. 


\title{
SECTION 1. Macroeconomic processes and regional economies management
}

\author{
Lloyd J.F. Southern (USA)
}

The status of small business growth and entrepreneurial start-up
capital availability during the current extended economic downturn

\begin{abstract}
Since the 2007 and 2008 economic downturn in the United States and most other countries of the world, it has become difficult for small business and entrepreneurial start-ups to obtain funds for expansion and seed capital even if they are brave enough to attempt to grow their businesses or startups in the depressed widespread economic conditions.

Different sources of possible funding are reviewed along with short and long term costs and benefits of each are discussed. Good decision making and wise choices are discussed and encouraged from a long term business success perspective.
\end{abstract}

Keywords: entrepreneurial startup capital, growth capital, venture capital, bank loans, growth of money supply, seed capital, angel investors, self financing, grants.

JEL Classification: M13.

\section{Introduction}

Since the 2007 and 2008 economic downturn in the United States and most other countries of the world, it has become difficult for small business and entrepreneurial start-ups to obtain funds for expansion and seed capital even if they are brave enough to attempt to grow their businesses or startups in the depressed widespread economic conditions (Anonymous, 2014a). Banks and traditional sources of loans have been facing failures among their members. Many banks have failed primarily due to losses from the shrinking housing and development sectors of the economy. Since the government has bailed out the major banks, many smaller banks have been taken over by the government and resold to new groups of investors. These new owners have demanded much greater security from new borrowers thus making it much more expensive and difficult for them to secure funds. Business expansions and new ventures that would have been easy to finance a few years earlier have become difficult or impossible to accomplish. Other sources of capital have likewise become more scarce, with greater security required and in many situations, no funds available at all (Entrepreneur Media, Inc., 2014).

During the years since the 2007 downturn, the future has been very uncertain with many economists predicting a rapid economic recovery while other groups of economists have predicted more and even greater future economic difficulties for the United States and most of the world. The United States recession was officially over several years ago and the official unemployment rate has

(C) Lloyd J.F. Southern, 2015.

Lloyd J.F. Southern, Ph.D., Professor of Management and Management Information Systems, Mercer University, Stetson School of Business, Mercer University Drive, USA. declined as the federal government has created various new stimulus activities and the Federal Reserve System had continued to buy new issued United States bonds. This activity has resulted in a huge additional increase in the national debt and a large increase in the money supply as the Federal Reserve has created new money to pay for buying these new federal bonds.

Much of this new money has been invested in the stock market due to very low interest rates available elsewhere. This is believed to account for much of the increase in stock values over the past few years. Banks also hold much of this new money which they pay its owners extremely low interest but they are afraid to make loans to many would-be borrowers (Cowling et al., 2014, January).

This is the situation brave would-be entrepreneurs and small business owners find themselves in when looking for a source of funding for their business. The future is certainly uncertain due to United States and world-wide economic and political conditions but there are still growth opportunities in some areas and activities in the United States and other countries (Koryah et al., 2015, February).

There are growth and new business opportunities developing as consumers taste and preferences change due to changing styles in dress, changing taste in entertainment, foods, and popularity of travel sites. Many of these changes and others are the results of demographic changes and income levels of the various age groups. Changes will be different in different parts of a given country and much greater in other countries where the original culture and values have traditionally been different.

When economic conditions are depressed in an area the citizens are more inclined to shop for needed 
and desired items which they perceive to be a better value. The average consumer in this situation will likely have an overall reduction in consumption. These changes can result in an increased demand for goods and services that are more economical thus creating opportunities for existing businesses to change their marketing mix and offering opportunities for new business to develop to supply these new needs and desires.

For the adventurous entrepreneurs and small business owners who are willing to expand in this environment there needs to be sources of funding available for them. As an effort to assist them we will look at various possible sources of funding that may be affordable in the present extended economic downturn (Anonymous, 2013).

So now we have the would-be entrepreneurs who need funds as seed capital to launch his or her new idea and the small business person who without additional funds cannot take their business beyond its present level of development. Traditionally, very small businesses have been funded with personal savings, credit cards, family and friend loans, and bank loans. Bank loans are more difficult because the bank is going to require some form of collateral as security for the loan. Most start-ups have little real assets to use as collateral for this type of loan. Later, as the businesses development, when they have amassed inventory, fixtures, and other hard assets, this type of loan is a real possibility.

Regardless of the source of start-up or growth funding, every business needs a detailed and well thought out business plan. This business plan should explain correctly the new business idea or expansion to prospective investors. It should also include selecting the right organizational plan for the business and the mission, objectives, and goals of the new business or business expansion. Purposed marketing strategies, planned location, and pro forma financial statement for two or more years should also be included (Lesonsky, 2009).

The business plan and its detailed contents will help in ensuring that the business will not fail but will survive and grow thus profiting the entrepreneur and increasing the general health of the local economy through increased taxes to federal and local governments and new job creation. Additional details will include such items as naming the business, finding the sources for needed products and/or the raw materials that will be needed, getting a license or permit from local or state government to conduct the business, and finding the best location for the business. Before any business is started there is need to do a thorough market research to determine if the proposed product or service is needed and if the demand that is not being met by other businesses is great enough to make the business or expansion profitable. One may also need to find a good accountant or lawyer to assist in setting up the legal structure of the business and assisting in finding financing for the business and later helping maintain proper financial and tax records.

\section{Funding for entrepreneurship and small business growth in a weak economy}

A weak economy is discouraging at best, but one should not let this prevent one from starting a new business or growing an existing business. Even though the United States and much of the other parts of the world are still in a weak economy that has lasted for several years, there are still opportunities for a devoted and hard working business person to seek. While all business expansions and new start-ups will need financing there are other skills and attributes that can make the start-up or expansion easier and less likely to fail or have a poor performing future. Some of these are superior knowledge and experience in the type of business and location being considered for expansion or start-up. Also an analysis of future economic forecasts, conditions of the local infrastructure and any plans by government agencies for improvements in roads and transportation networks, public transportation additions or other developments that would make it easier for potential customers to access the new business site. The work ethic of the owner and his/her reputation for fairness and reliability will be important to new and existing customers. With these factors in mind, many would-be entrepreneurs and small business owners would like to believe that if they have a good business idea and have prepared a detailed business plan that the needed funds it needs will be relatively easy to obtain. Entrepreneurs need to be very careful when searching for funds to finance the business they wish to start or expand that they don't search blindly for funds that are no place to be found. In most cases, start-ups are limited in the kinds of financing that they can obtain, this is because they require long-term debt financing in order to finance the start-up and any expansion they may be anticipating and future growth as well (Mason \& Stark, 2014). Small businesses seeking funds to advance to the next level of growth will have an easier task because they have demonstrated growth and survival over a period of time and will likely have assets that will permit them to seek funds from banks or other traditional lenders who require collateral to support the loan. This is also important if loans or grants are desired from a government agency or loans from a bank or other lender to be guaranteed by a government agency. It is also wise for the entrepreneur or small business owner to continue investigating the different ways of financing the business. This step is to ensure that the 
business will have other financial options in case the original planned source of funding develops problems or becomes unavailable (Anonymous, 2015).

Some sources of self-financing were mentioned earlier such as personal savings, personal credit cards, and loans from family members and/or friends. A relatively new source that has been used by some start-ups is "crowd sourcing". This is usually accomplished for start-ups that promise some type of social benefit such as a non-profit, some improvement to the environment, a popular new service or product that many in society would like to see available, or other activity that can gain the support of a broad group in society that would be willing to make a contribution or make a low interest or no-interest loans and take risks that a normal financial institution would not consider.

Self-funding is usually practical for only very small start-ups or growth. Larger businesses will need regular debt or equity financing. Most businesses will probably finance with more debt than equity. Although this approach may appear acceptable, it has several disadvantages such as negotiating credit terms that are available with various suppliers, which may result in restrictions on the flexibility of the entrepreneur or small business owner in future activities and also have high interest rates. Debt financing affects the balance sheet and will make the business less likely to be able to later obtain additional funding from either debt or equity. Apart from this, debt funding has the advantage in that it usually does not reduce the entrepreneur' or small business owner's equity in the business. This is not the situation if equity is given to a venture capitalist or other in order to obtain funding. On the plus side, debt financing may provide an advantage by being able to earn more return on the borrowed capital than the capital costs the business to use. In the present economy with low interest rates, this is an option to consider (Carter, 2009).

\section{Factors to consider while choosing a funding method for the new or growing business}

There are a number of additional factors to consider when seeking funding for a new or growing business. Initially, one should consider the priorities listed in the business plan as this will help one to know whether the need for funding is short-term or long-term and how quickly the business will be able to repay the loan or other investments received. Short-term funds are to be utilized primarily as working capital and should not be used to purchase fixed assets for the business. This is because if short-term funds are used to purchase fixed assets the business will lack the finances to repay the short-term loans since the business will not likely have generated significant profits at the early stage of its development.
The amount of capital to be raised should be carefully evaluated and outlined in the business plan. The amount to be raised should be carefully planned to have the right amount needed at the various stages of development and to help over financing. The business plan will also help to show how the funds will be utilized thus providing proof to the financial institution or to others providing the financing how the funds will be utilized for both operational needs and capital outlays. One should consider whether the business will need the total amount of the loan funds early or will need the funds in small monthly amounts. Consider the risks facing the new or expanding business and decide if whether you might want to take all the risks yourself or whether you would like to share risks with a partner. It is very important to know at what stage to ask for additional funding, this is because the risks involved in a business vary in degrees depending on the different stages of business growth (Morse, 2008).

When one has a good business idea and a detailed business plan, then all that one requires is the funds with which to start the new business or the expansion of an existing business. Most businesses, especially new start-ups, will require outside capital to begin operation for such things as physical facilities to house the business, funds for marketing, and to purchase fixtures, equipment, and starting inventory (Greco, 1995). In most cases, the failure of a business is blamed on poor management, but this blame may often be related to inadequate financing and poor planning of the business's finances. This has been observed in many failures as the businesses fail to manage their cash flow, resulting in forced closure.

\section{Funding the business}

After arriving at the total initial cost required establishing and beginning operations, the next step will be to decide on developing a financing pattern. The pattern will mainly depend on capital introduction into the business either by the owners' equity or through debt and/or equity financing. The amount to be obtained from outside financing will be dependent on the amount the business owner will be able to contribute, therefore, a comparative analysis will be needed in order to determine the most beneficial funding pattern for the business. Working capital needs to be considered, this entails inventories that need to be constantly maintained, and any credit services what will be extended to customers. The business can be funded using two known methods, namely debt financing and equity financing (Romans, 2013, August).

3.1. Financing through debt. Debt financing is when you borrow money and agree to repay the amount borrowed at a particular later time plus interest. This 
means that you have a debt to repay whether your business succeeds or not. Common debt financing is primarily obtained through loans from banks. Funds may sometimes be obtained from angel investors, individuals, or venture capitalist but they usually require giving equity in the business in addition to the business repaying the loan plus interest (Financial Literacy and Educational Commission, 2014).

\subsubsection{Advantages of debt financing. Total ownership} is maintained of the business when one borrows money from a lender such as a bank and is only obligated to pay back the money plus interest in the agreed manner and time. After payback, the relationship with the lender ends. Afterwards, the entrepreneur or small business owner will be free to operate as he or she chooses with no interference from outside sources other than legal rules and regulations.

Interest on business loans is treated as expenses to the business and as such is not subject to federal or state income tax. This has the effect of reducing the effective interest rate that the business pays.

For example, given that the bank or other lender charging as interest rate of $10 \%$ of the loan received and the business is subject to a tax rate of $30 \%$, the owner of the business will have an advantage in taking a loan given that in this situation, after taxes are considered, the effective rate of interest is only $7 \%$.

\subsubsection{Limitations of financing through debt. Even} though the tax advantage in reducing the effective rate of a loan may make the loan look advantageous, the interest rate may still be high because rates of interests are mainly affected by the economic conditions of the country, the owner's personal history of credit, and any credit rating of the business. Due to these factors, debt financing may prove to be rather expensive for the business. However, in the United States and many other countries interest rates are rather low and have been for several years due to governments striving to encourage growth in their economies through low cost financing for business and consumers. This approach however, has not been very successful in the United States and many other countries because of lack of perceived market growth potential, excessive regulations and other costs faced by business.

Another approach for obtaining loans is to provide security to the lender in the form of a mortgage. This will likely reduce the rate of interest charged but it may be difficult for starters to obtain this type of loan given that they are new entrepreneurs or young businesses and may lack assets to provide the necessary security for the loans they need. This technique may be more available when a business is seeking to expand and has amassed significant assets that may be used as collateral for new loans.
New businesses tend to have low credit ratings and even if the entrepreneur is successful in obtaining an initial start-up loan based on his/her personal credit rating he will likely find additional loans, before repaying the initial loan, that are needed for the business will be difficult to obtain and will be at a higher interest rate if available at all. Borrowing creates an obligation of paying back the loan plus interest. These payments are required whether the business is succeeding or failing, it is an obligation that has to be met. The problem arises when the business is not doing well due to poor management, a weak economy, completion, poor location or other reasons and one is still required to repay the loan. Given that a start-up business does not have large sales in the beginning and may even operate at a loss in early years of operation, loans must still be repaid or the business may face bankruptcy (DeBaise, 2010).

3.2. Financing through equity. This is a situation where one transfers part of what is owned in the business to others to persuade them to provide the financing needed to start or expand the business. In this situation, the risk of the new business loan is born by the investor and the entrepreneur together. If the business succeeds both parties win. The equity investor, usually referred to as a venture capitalist, gets the loan repaid with interest, but retains part ownership as his incentive for providing funding to the business and thus will receive a share of any future profits and increases in the net worth of the business (Clark, 2012). This kind of funding is very expensive as a way of funding growth of a business that is already successful, but may be cheaper and may provide the only way of obtaining financing for starting some new businesses that are unique in nature, involve new and unproven technology, and are not well understood by traditional lenders (Bloor, 2011, March).

One's own family may be a good source from which to get the funds for starting or expanding a business. Families tend to be very lenient when it comes to the repayment period and the expected returns on their investment. Although these are your relatives, you should still ensure that all necessary legal agreements are in place to avoid future problems, to ensure everyone is treated fairly, and to ensure good relations if further future funding is needed.

Personal credit cards are a source of financing for many small start-up and expansions. They are very useful and cheap given that some cards have low introductory rates. If these cards are well managed, they can be effective and if poorly managed they become very expensive due to increased interest rates and fees resulting from late repayments and overuse.

Trade credit may be obtained from vendors who supply some of your inventory. Their charges, if 
any, should be considered in comparison to other sources of funds (Huyghebaert, Van De Guchht \& Van Hulie, 2007).

In general, for startup small business funding, traditional funding is found to be the most suitable. Other sources may also be available especially for high-tech start-ups, the mew "green" businesses, and others viewed as having high growth potential such as new technologies, new inventions, and discoveries such as new drugs and medical treatments. Funding for expansion may be easier to obtain if the business has developed a history of growth and good rate of return on its initial investments.

3.3. Loans and grants from other sources. These kinds of funding from government agencies, private and public institutions that support certain activities and technologies and causes such as human health and safety are mostly for the start-up businesses that are viewed as having large future growth potential and are likely to contribute to improving the environment or some other worthy cause (Anonymous, 2014b).

Angel capital is a source of capital that comes from experienced entrepreneurs and wealthy individuals. Venture capital is composed of funds that come from institutional investors as well as some wealthy individuals. These funds are mostly given to people who are viewed by the investors as starting businesses with the potential for rapid growth and high future profit potential.

Another type of debt financing that does not require security or collateral is available where the lender charges a high interest rate but also has the option of converting the loan from being a debt to it becoming equity. This may be done if the owner of the loan fails to repay the loan. This kind of financing, irrespective of it having a high rate of interest, is highly preferred by some entrepreneurs since they do not need collaterals to secure the loan for starting or expanding their businesses. It also offers liquidity quickly and even though there is the fear that the debt may be converted to equity, in most cases the lender that issued the loan will not want to become an equity holder, thus in the end the business will still maintain its ownership as the lender issuing the loan will not take control of the company but will try to work with the borrower to repay the loan with interest (Kirsch, Goldfarb \& Gera, 2009).

3.4. Financing through hybrid. There are situations where an entrepreneur decides to combine both debt and equity financing for the new business. This situation makes it possible to calculate the debt/equity ratio. The ratio is obtained through dividing the total amount of debt that the business has by the total amount of equity that the owner has in the business.
Investors and lenders are mostly interested in this figure because it helps them to know how financially viable the business is and where their investments stand in the event the business becomes bankrupt. In the event of bankruptcy, debt holders are always given preference over investors in recovering their funds (Anonymous, 2009).

3.5. When to use debt financing. When one obtains a loan to finance a business or expansion it means that they are obligated to usually repay the loan in installments, which means that one needs to have plans for how they will use the funds. For example, if the loan is to be used for investing in fixed costs of the business such as purchase of land, buildings, or equipment, then it means that there is a likely chance of not receiving a cash return on this investment quickly. This will limit the growth of the business, as a debt investment needs to create a cash inflow, which means that it would be better if the money was invested in variable cost items that are more likely to create a positive cash flow. It is also important to consider the position of the lifecycle of the business. This is applicable to businesses that have already begun and only want funds for growth. Financing a business with loans is dangerous in the beginning of the business, as at that time the business is more likely to have low income or even operate at a loss, which may harm its ability to make loan payments. As the business continues growing and becomes more profitable, debt may be more advantageous as the business will face a higher tax rate thus offsetting part of the interest rate of borrowed funds. By this time in the life of the business, cash flow will be more predictable thus decreasing the risk of bankruptcy.

\section{Business plan}

When a starting business seeks funding from the government, investor capital, or even loans from a bank, there is the necessity for a business plan that helps to show how the business is planned to be conducted. The business plan is always the first impression of the proposed business to the prospective investors and helps by showing them the kind of potentials the business will have. It can also act as the last impression to the investors if in presenting the business plan one happens to make some critical mistakes (Liao \& Gartner, 2007). The investors who fund businesses for entrepreneurs have the opportunity of viewing many business plans, thus they always look for any errors that may cause them to say no to a particular business plan (Wagner, 2015, February).

4.1. Importance of a business plan. A proposed business must have a resume that will help to sale it to potential investors or lenders. The business plan helps to outline what the business is all about and the 
purpose for the business is communicated to people who view the plan. The plan helps to explain and illustrate the proposed business owner's vision to convince others to help him or her achieve that vision. Apart from being used by the stakeholders outside the business, the business plan helps the owner to focus on priorities that are achievable and helps to identify goals and objectives. There are some groups of individuals who should not see the business plan because it may provide them with information that they may use to the detriment of the business. This also applies to plans for business expansions or plans to add new activities as the business grows. This group includes property managers and realtors who may try to maximize their profits based on their view of the new or expanded business's potential. Generally, the business plan portrays the expected business expenses involved in opening the business, projected sales and expenses to be incurred during the actual operation and the estimated volume of sales the business is expected to generate to meet the owner's goals and objectives (Mainprize \& Hindle, 2007).

The business plan is also used for evaluation of the business operation. This is because it acts as a guide and a means to show the degree of progress attained and how well the business projections are being met over time. A viable business is adaptable to changes and the business plan will help in doing revisions as new goals need to be set and objectives modified (Bayon, 2008). The business plan also helps the business to know what goals have been achieved and what changes are needed to accomplish future growth in a dynamic business environment. A good tool to assist in evaluating decisions is to calculate the rate of return of one's investment. This relationship is calculated by obtaining the quotient between the total net profit realized and total investment made. The quotient is very low during the start or the initial stages of a business and grows as the business continues to expand. The rate of return needs to be compared with other forms of investments the entrepreneur might have made and related business types in one's industry so as to be sure one's business growth is close to what should be expected and to convince the owner he or she has make a wise investment.

4.2. Types of business plans. A business plan should describe the business principles (owners and management team), concept, markets targeted, and the products or services to be involved. The financial part of the plan should entail a full financial forecast of future earnings and costs and will help to convince financial institutions and other potential investors to lend funds to the business. The plan examines the total cost of a given business's start-up and projected financials over the next few years (Moyer, 2008). As the business is growing, there are various aspects of the business that will be affected, such as insurance, staffing, marketing, finances, taxes, licenses, and many other aspects as well. Thus, choosing a flexible funding plan that one can easily adjust as the business has begun and grown is of particular importance (Taylor, 2003).

\section{Other important aspects to consider before starting a business}

Before starting a business one needs to have relevant knowledge and expertise in the field or industry into which one is venturing. Basic knowledge of products and services to be involved in the business is also very important and is a major key to a successful business venture (Bromage, 2008). Limited business and financial knowledge may make starting and running a business an uphill task as one will be prone to making mistakes in many areas, missing opportunities, and perhaps accepting bad advice from vendors and suppliers and even violating normal operating and legal practices in one's industry.

A good entrepreneur is the one who explores the market in detail to know what products or services are demanded and if competitors are already meeting this demand. Verify that the unfilled demand for this product or service is great enough to make the new business profitable. If this is a new product or service a marketing plan will be necessary to create demand for the new product or service that is large enough to make the product or service profitable and ensure future growth potential. This new product or service may require marketing to new and different customers. Factors to consider will be does the customer come to the business's fixed location or does the business go to the customers as is the practice in many service businesses? If the business goes to the customer the location of the business is more flexible and the business will be more concerned about supply chain of its need for raw material and available employees with the correct skills and experiences. Other concerns are real estate costs, zoning, taxes, and infrastructure that provide access for travel to and from the location for the business' service personnel and employees. A business should only invest in products and/or services that have demands great enough to be profitable early and have enough growth potential for the business to prosper in the long term. It is obvious that some products are in greater demand than others both locally and nationally, also some product may be successful locally or may be more profitable if marketed nationally or internationally (Financial Literacy and Educational Commission, 2014). 
If the customers come to the business location, then safe adequate parking, public transportation, a location considered safe by the public and nearby access to other businesses that may provide appeal to your customers for their other wants and needs are important considerations. These factors may also make it easier to employ and maintain skilled retail employees. In choosing the final location for the business, the business person should choose the location viewed as having the greatest overall cost effective potential and one viewed as having growth potential and long run profitability.

5.1. Meeting competition. Unless the business is a monopoly, competition needs to be assessed to have dependable information about market competition at the present and projected for the future. The success of a business depends on the gap between demand and supply. In the event of an overwhelming demand for a product or service, one may be able to enter into the market in spite of completion. However, when competition exists an entrepreneur will need to be stronger than the competitors or have some competitive advantage when entering into a competitive market (Kolacek, 2009). Information such as who the competitors are, where they are located, and any unique advantage they may have will help the new business develop unique products or services and a marketing approach that will be very important for the success of the new or growing business, especially at start-up, as they will assist in the survival and early growth of the business.

5.2. Legislation. There are certain compliances that a business must meet before becoming licensed to operate. Different nations, states and cities have varied laws and regulations of compliances. Details concerning such rules and regulations need to be obtained, adhered to, and respected. Any special licenses and permits will need to be obtained and maintained. This information should be obtained and understood before one makes a location decision because certain types of businesses are restricted by zoning codes or other regulation to specific locations. Lack of expertise in this area may call for the services of lawyers or other professionals. Failure to comply with the set rules and regulation will lead to penalties such as fines and possible forced relocation that will hamper the success of the business (Edwards, 2009).

5.3. Labor. For a business to succeed, labor with the correct skills and experiences and in the needed numbers will be needed. This calls for careful selection of employees since they are the ones who will greatly determine the success or failure of the business (Doms, Lewis, \& Robb, 2010). The cost of labor will be determined by the qualifications required and location of the business as some areas are endowed with the desired type of labor while other areas have scarcity of the skills needed. The size of the business will also determine the number of employees required and those with special skills such as supervisors, managers, and any special technical personnel. In the current economic environment many businesses are cutting the number of employees and embracing more technology. This may be an advantage to new startups by providing a larger pool of potential employees from which to choose (Spicer, 2009). One also needs to stay abreast of government regulations concerning how one must administer labor rules, regulations, working conditions, safety issues, environmental issues, and other requirements. These considerations will vary in different countries and even among states and territories in a given country.

5.4. Technology. During the start of a business, it is advisable to invest in the best and latest technology one can afford. Choosing the best and latest technology to employ is not an easy task and continued future monitoring of technology is important to stay abreast of the most efficient and economical equipment and computer technology available. Technology can help to reduce some cost, reduce the number of employees needed, and increase efficiency in the operation of the business. A business, which embraces technology in its initial stages, is more likely to develop and prosper much better in the long run than a business that does not employ available technology (Anonymous, 2010).

\section{Conclusion}

History repeats itself, and history has proven that down markets do arrive and eventually end and prosperous economic conditions return. In the present long term downturn, conditions have been very slow to significantly improve. Many economists and business people are concerned about the massive national debts the United States and many other countries have created as they strive to grow their economies and reduce unemployment. Future economic conditions are more difficult to predict. There are many different predictions with some believing the economy in the United States and other countries will continue to improve while others believe conditions may get worse before they get significantly better. Entrepreneurs and small business owners who are striving to grow their business need to be vigilant and strive to obtain the best economic forecasts available in order to be proactive instead of reactive concerning future events. In poor economic times, it is obvious that business will grow at a slower rate but slow growth is better than negative or no growth at all. It is very important to assess all the total project costs that are 
required to run the business efficiently and effectively and to strive to reduce these costs through better management, training, and the use of current technology. One should strive to be aware of the overall economic and political trends in the nation, world, and especially one's own industry and specific location (Henderson and Weiler, 2010). Some locations may be economically depressed while at the same time locations not far away may present good potential. Thus one should try to evaluate this situation before choosing one's business location. By maintaining awareness of changing economic conditions, customers' tastes and preferences, new products and innovations in the products and services one's business provides, and the changing political environment which may result in new and or different laws and regulations, the alert business person will not be caught unaware as these changes occur. Some of these future changes may be an advantage for the business while others may impact the owner's control of the business and add additional costs of compliance. By being ever aware of changing conditions the business has an enhanced chance of better future growth, profitability, and long-term survival (Nagashyhayeva et al., 2014, March).

\section{References}

1. Anonymous. (2009). National Holding Company; Tips for small business funding during credit crunch, Economics and Business Work, 13.

2. Anonymous. (2010). Maryland Industry Focus: Information technology, The Daily Record, Baltimore.

3. Anonymous. (2013). Using personal finances. Available at: www.sba.gov/content/using-business-via-personal-financies.

4. Anonymous. (2014a). In search of funding: 7 core principles to raise capital, Mighty Wise Media.

5. Anonymous. (2014b). Grants. Available at: www.sba.gov/content/grants.

6. Anonymous. (2015). Borrowing money for your business. Available at: www.sba.gov/content/borrowingmoney.

7. Bayon. (2008). The high-performance entrepreneur: Golden rules for success in today's world, South Asian Journal of Management, 15 (3), p. 150.

8. Bloor. (2011). 8 venture capital sources for your startup. Available at: http://ventureburn.com2011/03/08-venturecapital-sources-for-your-startup.

9. Bromage. (2008). Ways to make your business a success. England: How To Books Ltd., $3^{\text {rd }}$. ed.

10. Clark. (2012). Want venture capital funding? Here' how. Available at: www.forbes.com/sites/dorieclark/ 2012/07/16/whats-next-for-venture-capital.

11. Cowing, Lili, Ledger \& Zhang. (2014). What really happened to small and medium-sized enterprises in a global economics recession, International Small Business Journal.

12. DeBaise. (2010). Building your business: start-ups will keep struggling in 2010, Wall Street Journal (Eastern Edition), B, 1.

13. Doms, Lewis \& Robb. (2010). Local labor force education, new business characteristics and firm performance, Journal of Urban Economics, 67 (1) p. 61.

14. Edwards. (2009). Sarbanes-Oxley Act on trial: local CPA takes on law, panel in high court for overregulation, McClatchy-Tribune News, Washington.

15. Entrepreneur Media Inc. (2004). How to raise money for your business. Available at: www.entrepreneur.com/how to raisemoney.

16. Financial Literacy and Educational Commission. (2014). Is your business fiscally fit? Available at: www.sba.gov/content/borrowingmoney.

17. Greco \& Michman. (1995). Retaining triumphs and blunders: Victims of competition in the new age of marketing management. Westport, CT: Ouorum Books, 11

18. Henderson \& Weiler. (2010). Entrepreneurs and job growth: probing the boundaries of time and space, Economic Development Quarterly, 24 (1), p. 23.

19. Huyghebaert, Vande Gucht \& Van Hulle. (2007). The choice between bank debt and trade credit in business startups, Small Business Economics, 29, pp. 435-452.

20. Kirsch, Goldfarb \& Gera. (2009). Form or substance: The role of business plans in venture capital decision making, Strategic Management Journal, 30 (5), p. 497.

21. Kolacek. (2009). The leadership road: Positive actions that drive results, Journal of Applied Management and Entrepreneurship, 14 (3), p. 117.

22. Lesonsky. (2009). Allbusiness.com, The Small Business Blog, McClatchy-Tribune Business News, Washington.

23. Mainprize \& Hindle. (2007). The benefit: A well-written entrepreneurial business plan is to an entrepreneur what a midwife is to an expecting mother, The Journal of Private Equity, 11 (1), p. 40.

24. Merchant. (2007). Competing in emerging markets. Routledge.

25. Morse. (2008). Entrepreneurs: Generating cash in a credit crunch, Ivey Business Journal Online, 72 (6), p. 1.

26. Moyer \& Kretlow. (2008). Contemporary Financial Management, South-Western.

27. Smith-Broady. (2009). Location key to business success, McClatchy-Tribune Business News, Washington.

28. Spicer. (2009). Recession is a good time to start a venture, Rochester Business Journal, 25 (39), p. 8.

29. Taylor. (2003). Bookkeeping and accounting for the small business. England: How To Books Ltd., $8^{\text {th }}$ ed. Available at: www.culture-at-work.com/copyright. 